\title{
Early seventh-millennium AMS dates from domestic seeds in the Initial Neolithic at Franchthi Cave (Argolid, Greece)
}

\author{
Catherine Perles, Anita Quiles and Helene Valladas
}

\begin{abstract}
:
When, and by what route, did farming first reach Europe? A terrestrial model might envisage a gradual advance around the northern fringes of the Aegean, reaching Thrace and Macedonia before continuing southwards to Thessaly and the Peloponnese. New dates from Franchthi Cave in southern Greece, reported here, cast doubt on such a model, indicating that cereal cultivation, involvingnewlyintroducedcropspecies, began during the first half of the seventh millennium BC. This is earlier than in northern Greece and several centuries earlier than in Bulgaria, and suggests that farming spread to southeasternEuropebyanumberofdifferentroutes, including potentially a maritime, island-hopping connection across the Aegean Sea. The results also illustrate the continuing importance of key sites such as Franchthi to our understanding of the European Neolithic transition, and the additional insights that can emerge from the application of new dating projects to these sites.
\end{abstract}

Keywords: Greece, Franchthi Cave, Initial Neolithic, seventh millennium BC, farming, radiocarbon dating

\section{Introduction}

Ever since Clark's pioneering mapping of the earliest Neolithic radiocarbon dates in Europe (Clark 1965), radiocarbon chronology has played an essential role in the development of models for the origins and spread of the Neolithic (Ammerman \& Cavalli-Sforza 1971, 1984; Renfrew 1973; Gkiasta et al. 2003; Pinhasi et al. 2005; Davison et al. 2006; Rasse 2008; Bocquet-Appel et al. 2009). As Vander Linden observes, “... interpretative models of the spread of the Neolithic are tributary to readings of its temporal structure" (Vander Linden 2011: 29).

Due to its geographical location and early dates for the Neolithic, Greece usually appears in these broad-scale models as the origin of the spread of farming economies in Europe. These models, however, rest on a fragile basis, since there is actually no consensus on the mechanisms, timing and route of penetration of a Neolithic economy in Greece (e.g. Thissen 2000, 2005; Kotsakis 2001; Runnels 2003; Sampson 2005; KyparissiApostolika 2006; Weninger et al. 2006; Sef' eriad' es 2007; Perl' es 2010). Depending on the presumed origin-local, western Anatolian, or multiple origins-and on the postulated mechanisms - indigenous development, spread by terrestrial or maritime routes, reaction to the ' $6200 \mathrm{cal} \mathrm{BC}$ climatic event' (Alley et al. 1997) — dates older than 6200 or $6400 \mathrm{cal} \mathrm{BC}$ are either rejected or, on the contrary, readily accepted. In the most extreme statements, dates as far apart as $7000 \mathrm{cal} \mathrm{BC} \mathrm{(Perles} \mathrm{2001)} \mathrm{and} 6200 \mathrm{cal} \mathrm{BC}$ (Weninger' et al. 2006) have been defended for the earliest occurrence of the Neolithic in Greece. The late date hypothesis aligns the Greek Neolithic with that of the southern Balkans, thus supporting the view that the Neolithic colonisation of Europe originated 
Early seventh-millennium AMS dates from domestic seeds in the Initial Neolithic from western Anatolia and was triggered by the deleterious effects of the ' $6200 \mathrm{cal} \mathrm{BC}$ climatic event'. By contrast, according to the early date hypothesis, no climatic event can be invoked to explain the spread of the farming economy. Furthermore, the early date hypothesis supports a model of multiple origins for the European Neolithic since the early Neolithic in western Anatolia, which is clearly related to that of Bulgaria, may not be earlier than the earliest Greek Neolithic.

\section{The earliest Neolithic in Greece: a debated issue}

This debate, however, is relatively recent. When dates of c. 7000 cal BC for the early Neolithic of Greece were published in the 1960s and early 1970s, their antiquity posed no major problem. The debate between proponents of traditional 'short' chronologies and proponents of the new, 'long' ${ }^{14} \mathrm{C}$-based chronology had abated (Renfrew 1973), and the Greek Neolithic was commonly considered a direct outcome of the Near Eastern Neolithic, itself of greater antiquity (e.g. Weinberg 1970; Theocharis 1973). However, among the four sites with ${ }^{14} \mathrm{C}$ dates from the first half of the seventh millennium, Nea Nikomedeia (Macedonia) was later re-dated by AMS and none of the new dates, on carbonised seeds, predated $6400 \mathrm{cal}$ BC. The two oldest determinations from Argissa (Thessaly) were made on bone, had no precise provenance, and could be considered unreliable. Knossos (Crete) and Franchthi (Argolid) were thus the only two remaining sites suggesting that the introduction of a farming economy in Greece dated back to the first half of the seventh millennium (see compilations in Reingruber \& Thissen 2005, 2009).

The rejection of the early ${ }^{14} \mathrm{C}$ dates from Franchthi and Knossos only occurred in the late 1990s, after the first settlements in western Anatolia and Thrace-the presumed direct ancestors of the Greek Neolithic-were excavated and dated at the time to the end of the seventh millennium cal BC. Thissen in particular then stated that, since the early Neolithic in western and north-western Turkey did not go back further than c. $6200 \mathrm{cal}$ BC, the Greek Neolithic could be no older (Thissen 2000: 161, see also Thissen 2005). He recognised nevertheless that an 'aceramic' Neolithic was represented at Knossos and Franchthi, but he considered these episodes as brief and of strictly local significance. More recently, Reingruber and Thissen (2009), despite abundant stratigraphic and artefactual evidence to the contrary (e.g. Jacobsen \& Farrand 1987; Vitelli 1993; Perles 2004), rejected the presence of an Early' Neolithic at Franchthi and in the Peloponnese. As a consequence, the earliest Neolithic in Greece would have been that of Thessaly, around 6500/6400 cal BC, in line with the more recent dates from western Anatolia, while the Peloponnese would have lagged behind until about $6000 \mathrm{cal}$ BC (Reingruber \& Thissen 2009: 762).

An even more drastic stand was taken by Weninger and his collaborators who rejected all dates older than $6200 \mathrm{cal}$ BC. They concluded that Macedonia (Nea Nikomedeia) and Thessaly (Sesklo and Achilleion) were first settled during 'the $6200 \mathrm{cal}$ BC event' and considered '...that the $8200 \mathrm{cal} \mathrm{yr} \mathrm{BP}$ aridity triggered the spread of early farmers out of Anatolia into Greek Macedonia as well as in the fertile floodplains of Thessaly...' (Weninger et al. 2006: 417). Franchthi and Theopetra (Thessaly), as 'cave sites', had been left out of the discussion. 


\section{Catherine Perlès, Anita Quiles \& Hélène Valladas}

These readings of the dates are clearly linked to the hypothesis that the Greek Neolithic must come from western Anatolia, and, therefore, cannot be older than the latter. In the meantime, however, one of the present authors (CP) had argued that the influence of western Anatolia was limited to Macedonia. Other origins, through repeated episodes of maritime colonisation, had to be sought for the establishment of the Neolithic further south (Perles 2005, 2010). According to this model, the dates from western Anatolia no longer constituted a terminus ante quem, and the multiple origins that were argued for made it possible to accept a wider range of dates.

Given the importance of the site of Franchthi in the debate and the unreliability of radiocarbon dates obtained more than 30 years ago, new dates on the Initial Neolithic at Franchthi were clearly required. We shall report here on a series of charcoal and seed AMS determinations related to the Mesolithic-Neolithic transition at Franchthi, including two dates on seeds of domesticated wheat.

\section{The context}

Franchthi Cave and the open-air settlement called 'Paralia', overlooking Koiladha Bay in the south-western Argolid (Figure 1), were excavated between 1967 and 1979 under the direction of T.W. Jacobsen of Indiana University (Jacobsen \& Farrand 1987). The trenches were excavated in shallow passes (the 'units'), following variations in the sediment. All trenchesweredry-sievedwithameshof $3 \mathrm{~mm}$. Flotationandwatersievingwereimplemented at trenches FAN, FAS, H1A and H1B, down to a mesh of $1.5 \mathrm{~mm}$ (Diamant 1979). The exceptional archaeological sequence at Franchthi spans from the early Upper Palaeolithic to the Final Neolithic, but we shall concentrate here on the later Mesolithic and earliest Neolithic deposits.

The cultural phasing and the correlations between the different trenches have been established on an archaeological basis, within the framework of on-going work by Perles ` aimed at producing a general synthesis of the site. It takes into account all the data provided by archaeobotanical remains (carbonised seeds), archaeozoological remains (mammal bones, 


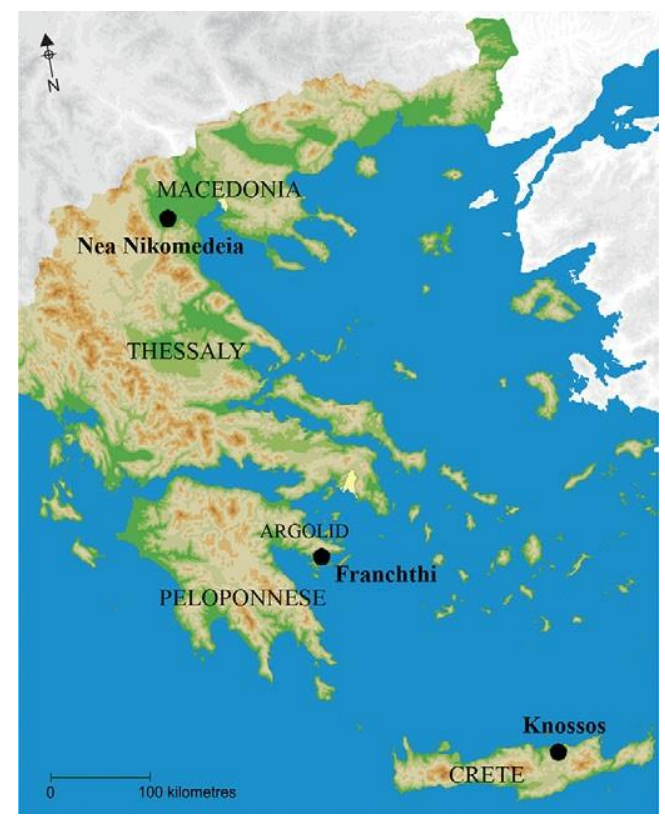

Figure 1. Map of Greece showing the location of Franchthi Cave and other regions and selected sites mentioned in the text.

fish bones, marine molluscs and land snails), lithic assemblages and ornament assemblages.Inthereferencetrenches,FAN

The Upper Mesolithic was excavated in trenches, FAS, FAN, H, H1B, H1A and G1 (Figure 2). It is characterised by intensive tuna fishing (Rose 1995) and a very specific lithic assemblage, which comprises numerous atypical non-geometric microliths (Perles 1990). 'It has already been ${ }^{14} \mathrm{C}$ dated by six conventional radiocarbon determinations. With one exception, they give coherent results between c. 8400 and $7400 \mathrm{cal} \mathrm{BC} \mathrm{(2 \sigma )}$ (Table 1). This phase has not been re-dated. (The outlying sample comes from H1A, at the limit between the Lower and Upper Mesolithic. The date clearly indicates a Lower Mesolithic contamination.)

The Final Mesolithic is present in situ in FAS and FAN (Stratum X1) but is suspected to be reworked in H1A and H1B, due to deep post-Neolithic excavations (Vitelli 1993: 33). Both tuna vertebrae and non-geometric microliths have virtually disappeared. New transverse arrowheads appear, and the economy relies on a diverse spectrum based on wild fruit, legumes, cereals, a few land snails and the hunting of red deer, hares, turtles and foxes (Munro \& Stiner 2012). The Final Mesolithic had not been ${ }^{14} \mathrm{C}$-dated previously in the reference trenches. Two dates from other trenches (G1 22 and FF1 43A1), around 7500-6700calBC, were potentially compatible with theFinal Mesolithic but the attribution could not be fully confirmed on an archaeological basis. Three new charcoal samples from reliable contexts, FAN 169 and FAN 166, were thus submitted for analysis. 
In the Initial Neolithic, domestic sheep, goats, wheat (Triticum dicoccum) and barley (Hordeum distichum) appear in small quantities (Payne 1975; Hansen 1991), together with trapezes on pressure-flaked blades (Perles 1990). The Initial Neolithic was labelled

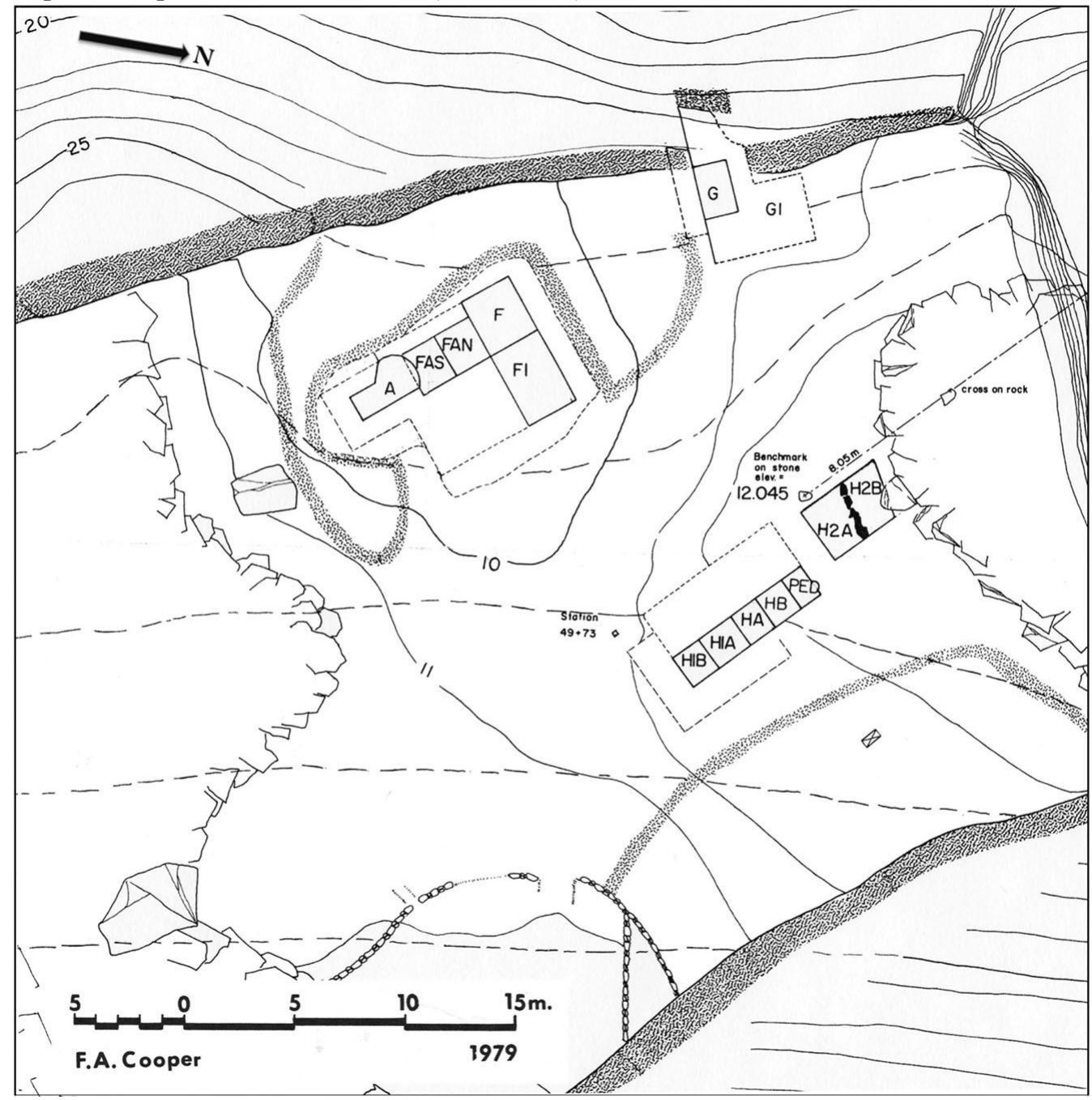

Figure 2. Location of the trenches discussed in the text (after Jacobsen \& Farrand 1987).

as "possibly aceramic Neolithic" in a preliminary report (Jacobsen 1969: 352) in view of the very small number and small size of the sherds it contained, but this denomination was not retained subsequently by the Franchthi specialists (see 'Initial Neolithic' in Perles' 1990; 'Interphase 0/1' in Vitelli 1993). In FAN, FAS and possibly FF1, it corresponds to the well-defined sedimentary stratum called the 'grey clay' by the excavators (Farrand 2000: 50-51). 
Early seventh-millennium AMS dates from domestic seeds in the Initial Neolithic

According to Farrand (2000: 50), five dates could be attributed to the 'grey clay' (Stratum X2). Two of them, however, FF1 43A1 and FAS 146, come from units that Farrand himself did not list as included in Stratum X2. Examination of the sections shows that FAS 146 may have cross-cut the underlying rocky deposit. The exact lithostratigraphic position of FF1 43A1 cannot be established, but both Perles (1990) and Vitelli (1993) consider it as` 


$\begin{array}{llll}\text { Th } & & \text { ltu } & \text { ltu } \\ \text { isd } & \text { Ta } & \text { ral } & \text { ral } \\ \text { ate } & \text { bl } & \text { att } & \text { att } \\ \text { cle } & \text { e1. } & \text { rib } & \text { rib } \\ \text { arl } & \text { Sy } & \text { uti } & \text { uti } \\ \text { yre } & \text { n } & \text { on } & \text { on } \\ \text { fer } & \text { nt } & \text { co } & \text { co } \\ \text { sto } & \text { he } & \text { ul } & \text { ul } \\ \text { th } & \text { sis } & \text { dn } & \text { dn } \\ \text { e } & \text { of } & \text { ot } & \text { ot }\end{array}$

av

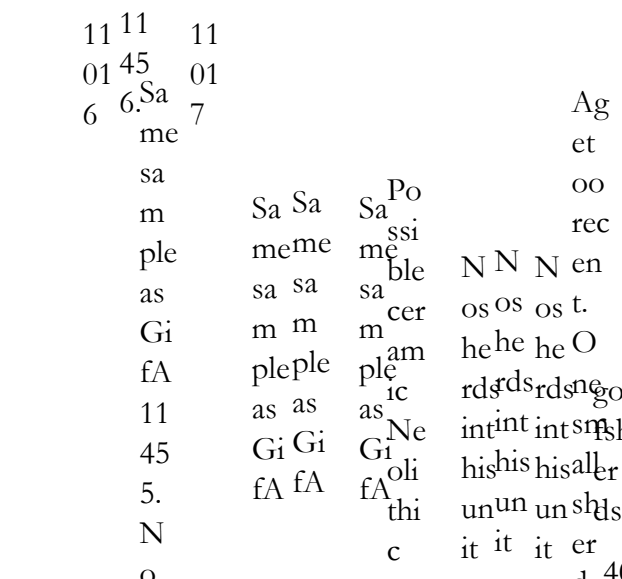

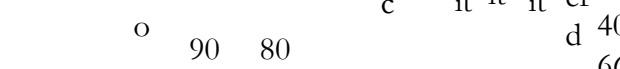

13

09

12

6-

86

27

92

38

yin ${ }_{\text {oli }}$

thi11 12109090

c 0708094976 9428933847

$8-2-8---$
7679757674

0844980787

8284828177

0619019883

----
7576757573

$89618088 \overline{10}$ 1A1AA A A

$1110 \mathrm{~N} \mathrm{~N} \mathrm{~N}$

7( 1P17 1717

Re167P7P7P

Sidt4 20 21 21

ue ch 960607

s) $\operatorname{arcch} \mathrm{ch} \mathrm{ch}$

P1 oalarc arcarc

$6689 \mathrm{oal}^{\mathrm{Oaloa}}$

6c 40878785

ha 103030

rc

oal

87

40 \begin{tabular}{l|l|l}
73 & 70
\end{tabular}

$16 \quad 66$

$-$

$70 \quad 68$

be be $76 \quad 15$

\begin{tabular}{lll|l} 
co & co & 74 & 71
\end{tabular}

\begin{tabular}{lll|l} 
nfi & nfi & 93 & 74
\end{tabular}

$\mathrm{rm} \mathrm{rm}$

ed ed

7070

\begin{tabular}{ll|l}
612142 & 04 \\
- & 0
\end{tabular}

$686668 \quad 67$

$319728 \quad 08$

$707070 \quad 72$

$763257 \quad 40$

- - - -

$676667 \quad 65$

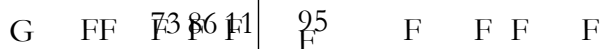

1214 A A A AS A A A A

$\begin{array}{llllllll}2 \mathrm{P} & 3 \mathrm{~A} & \mathrm{~N} \mathrm{~N} \mathrm{~N} & 14 & \mathrm{~N} & \mathrm{~N} \mathrm{~N} & \mathrm{~N}\end{array}$

$\begin{array}{llllllll}15 & 1 \mathrm{P} & 161616 & 6 \mathrm{P} & 16 & 1616 & 16\end{array}$

$\begin{array}{lllll}36 & 15 & 9 & 6 & 6 \mathrm{~b}\end{array}$

th 26 Gifits

arc ch fAfAif

oal arc $8080 \mathrm{~A} \&$

81 oal 040400

$\begin{array}{lll}90 & 80 & 9 \mathrm{c} 6 \mathrm{c} 48\end{array}$

20 ha hach

rc rc arc

oaloaloa

807979

253590 d 40

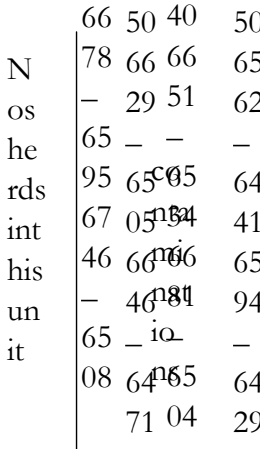

14

069010

827007

$2-23025$

$64-8 \theta\{$

666666

704888

5370709

- 58806

64

236565

9272

50

A6 $\quad \mathrm{FF}_{\mathrm{F}} \quad \mathrm{F} \quad \mathrm{F} \quad \mathrm{F}$

3P $14 \mathrm{AS}^{\mathrm{A}} \mathrm{A} \mathrm{A}$

$134 \mathrm{~B}_{14} \mathrm{~N} \mathrm{~N} \mathrm{~N}$

$92 \quad 5 \mathrm{P}_{3 \mathrm{P}} 151515$

ch $152098 \quad 1$

有c 274 GiGiGi

oal ch ch fAfAfA

$77 \quad \operatorname{arc}_{\operatorname{arc}} 808080$

$90 \quad \mathrm{oal}_{\mathrm{Oal}} 040404$

7979 5c 4c 3c

$00{ }_{30}$ ha ha ha

rc rc rc

oaloaloal

787579

755510 
Table 2. New AMS radiocarbon dates from the Final Mesolithic and Initial Neolithic at Franchthi Cave. Delta ${ }^{13} \mathrm{C}$ values were measured on the Artemis accelerator mass spectrometer.

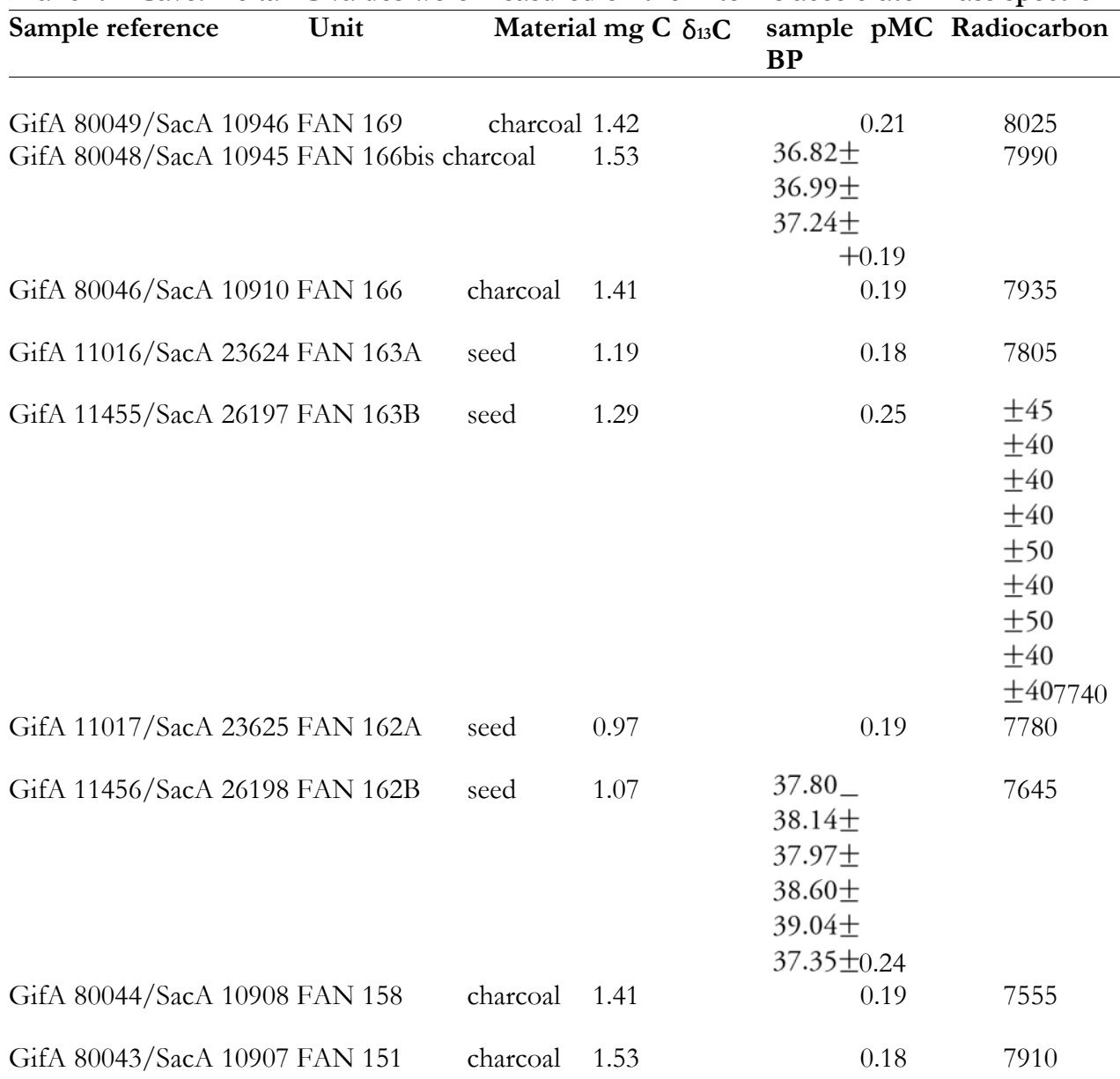

probably Final Mesolithic. A third sample, from trench A, comes from a unit (A 63) with suspected Middle Neolithic contamination (Vitelli 1993: 37). Accordingly, only the dates from FAS 143 and FF1 44B5 could be securely attributed to the 'grey clay' stratum and can be considered to date the earliest Neolithic deposits at Franchthi. Both units were devoid of sherds.

We submitted three additional Initial Neolithic charcoal samples for dating (FAN 159, 158 and 151), all included within the 'grey clay' stratum. No sherds were found in unit FAN 159, one 'chip' was found in unit FAN 158, and 33g of sherds in unit FAN 151 (Vitelli 1993: 226). Of these three Initial Neolithic samples, two (FAN 159 and 151) gave ${ }^{14} \mathrm{C}$ dates so close to Final Mesolithic dates that the charcoal could be suspected to be intrusive, while the third (FAN 158) gave a date younger by several centuries, corresponding to the Early Neolithic (Table 2). We thus decided to date indisputable carbonised seeds of Triticum dicoccum from the same stratigraphic context. However, domestic seeds are not abundant in the Initial Neolithic (Hansen 1991: 139-44) and we 
were only allowed to take samples in units with around 10 seeds of wheat. The best potential sample, from FAS 145, could not be located. We thus chose two seeds identified by Hansen as T. dicoccum from unit FAN 163, at the interface of the rocky layer X1 and the 'grey clay' (X2), and from the overlying unit FAN 162, at the base of the 'grey clay' stratum (Figures 3 and 4). The lithics from both units show some mixing of Final Mesolithic and Initial Neolithic (Perles 1990: 91-93), but there is no wild progenitor of wheat in Greece and wheat was introduced as a domestic species in the Neolithic. These domestic seeds thus necessarily date the Neolithic, not the Mesolithic.

\section{Methods and results}

The dated samples were pre-cleaned according to the ABA pre-treatment. They were then oxidised to $\mathrm{CO}_{2}$, reduced to graphite and compressed into pellets for measurement at the Artemis accelerator mass spectrometer facility (CEA, Saclay) (Arnold et al. 1987).

The new AMS dates are given in Table 1 together with the previous ${ }^{14} \mathrm{C}$ results from Franchthi, and detailed in Table 2. The calibrated ranges (Figure 5) are plotted as a function of time on the IntCal09 calibration curve (Reimer et al. 2009). The curve shows 
Early seventh-millennium AMS dates from domestic seeds in the Initial Neolithic

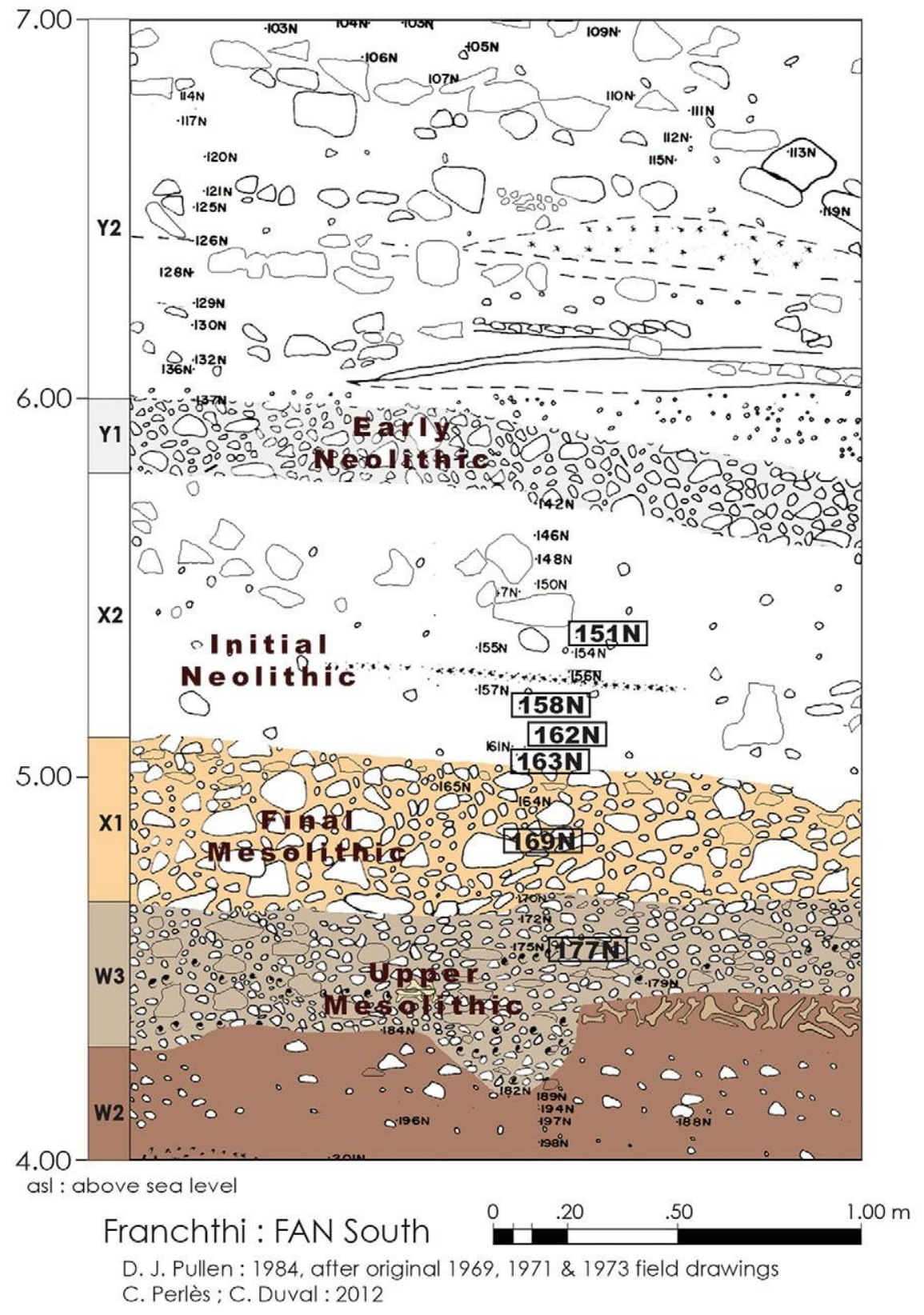

Figure 3. Detail of the south section of trench FAN showing the stratigraphic position of the radiocarbon-dated samples (after Jacobsen \& Farrand 1987).

several irregularities that reflect the variability in the level of atmospheric ${ }^{14} \mathrm{C}$ in the period concerned. The first centres around $8700{ }^{14} \mathrm{C} \mathrm{BP}$, and corresponds to the cluster of Upper Mesolithic dates. The calendar ages deduced range from 8200 to c. $7500 \mathrm{cal}$ BC, an 
interval probably much longer than the actual duration of the phase. A second plateau occurs

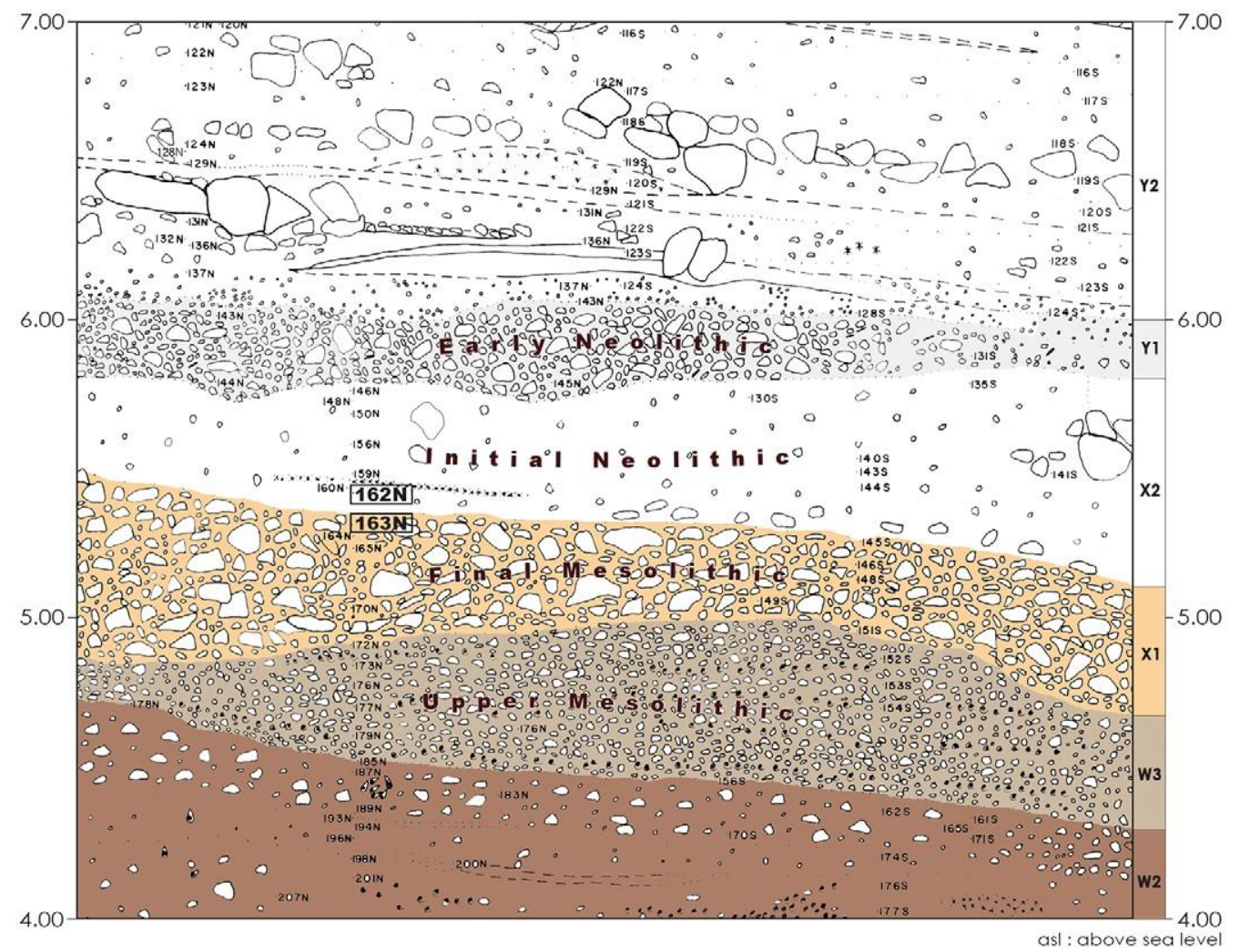

Franchthi : FA East

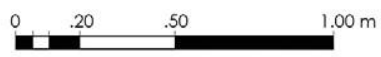

D. J. Pullen : 1979, 1985, C. Perlès ; C. Duval : 2012

Figure 4. Detail of the east section of trench FA showing the position of the two radiocarbon-dated seeds in relation with the lithostratigraphy (after Jacobsen \& Farrand 1987).

around $8000-7800{ }^{14} \mathrm{C} \mathrm{BP}$, the interval which contains most of the Final Mesolithic and Initial Neolithic dates. Even AMS dates with standard deviations of $c$. +-40 or 50 years thus correspond to time intervals of several hundred years after calibration (between $c$. 7000 and $6500 \mathrm{cal} \mathrm{BC}$ at $2 \sigma)$.

In order to obtain a more precise picture of the cultural chronology at Franchthi, we used the ${ }^{14} \mathrm{C}$ dates and the stratigraphic sequence to construct a Bayesian model using the OxCal 4.1.7 software, which incorporates the IntCal09 calibration curve (Bronk Ramsey 2009; Reimer et al. 2009).

This approach allows the stratigraphic information from the site to be integrated as $a$ priori to the radiocarbon likelihoods in order to determine a posteriori probabilities taking 
into account all the available information (Bronk Ramsey 2001, 2009). According to the archaeological data, the Upper Mesolithic, Final Mesolithic and Initial Neolithic samples were incorporated into three different phases nesting in a sequence (Figure 6). The very early date from H1A 117 Trench, a unit at the interface of the Upper and Final Mesolithic, was eliminated since it clearly corresponds to the Upper Mesolithic (Table 1). Units

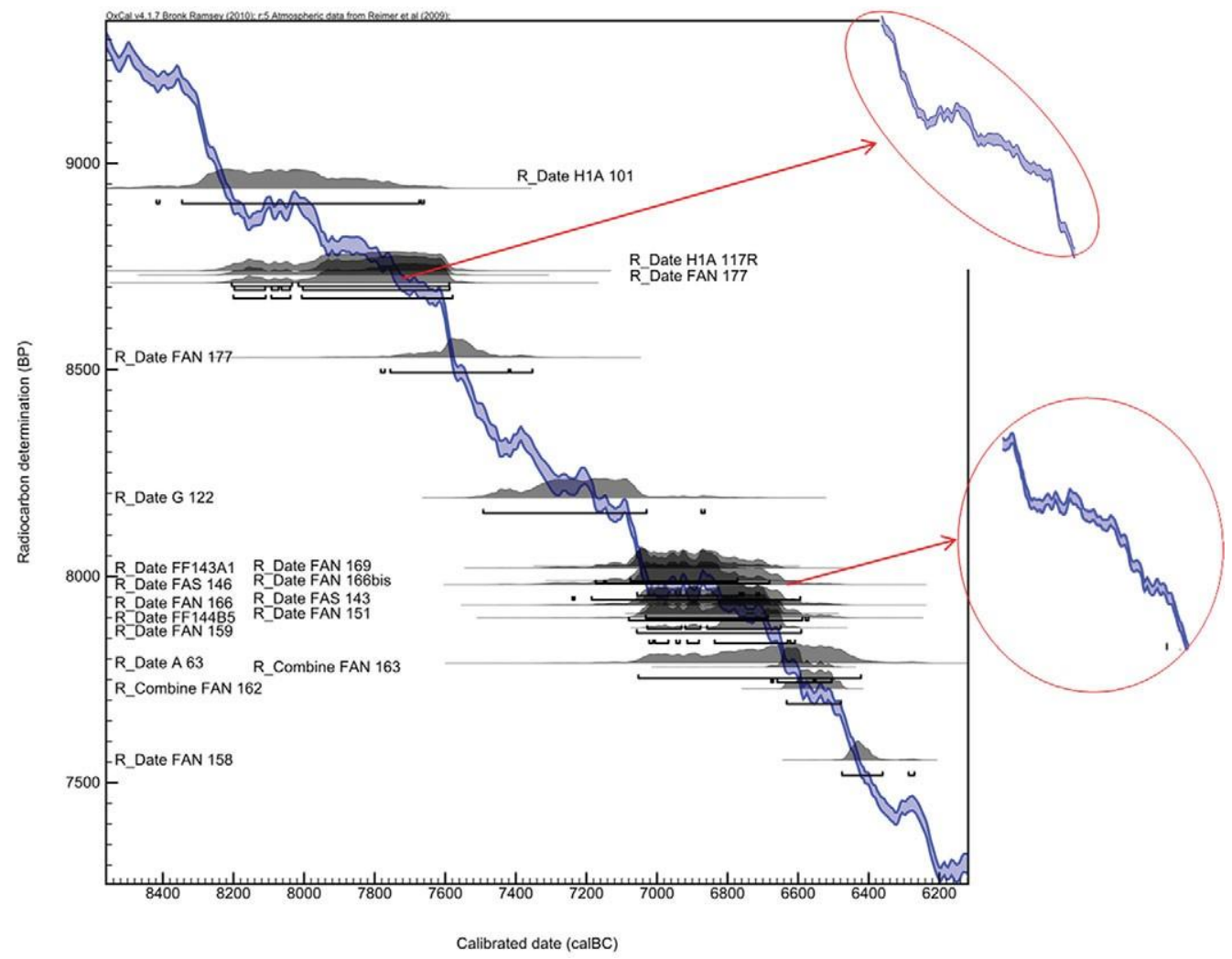

Figure 5. Projection of the Upper Mesolithic, Final Mesolithic and Initial Neolithic dates from Franchthi on the IntCal09 calibration curve (Reimer et al. 2009).

cross-cutting the Final Mesolithic and the Initial Neolithic were grouped as a separate cluster, in its correct stratigraphic position. Units coming from the same trench have been listed in their stratigraphic order within each phase. An outlier test was performed and the model was accepted $($ Amodel $=111)$. This confirms that there exist diachronic differences between the three phases, even if the time gap between the Final Mesolithic and the Initial Neolithic is clearly short. In order to exclude the influence of the suspiciously young date from FAN 158 (Initial Neolithic), the model was re-run without this sample. The diachronic model was again confirmed (Amodel $=112$ ): both stratigraphy and radiochronology agree. 


\section{Discussion}

The dates obtained on the carbonised seeds indicate without any possible doubt that cereal agriculture was practiced in southern Greece during the first half of the seventh millennium. The dates from seeds are younger by about 200 years than the dates obtained on charcoals from the same lithostratigraphic context, a difference usually attributed to the 'old wood' effect. Charcoal dates for the Initial Neolithic are very close to Final Mesolithic ones, which may suggest some Final Mesolithic contamination. Looking at the sections, that is

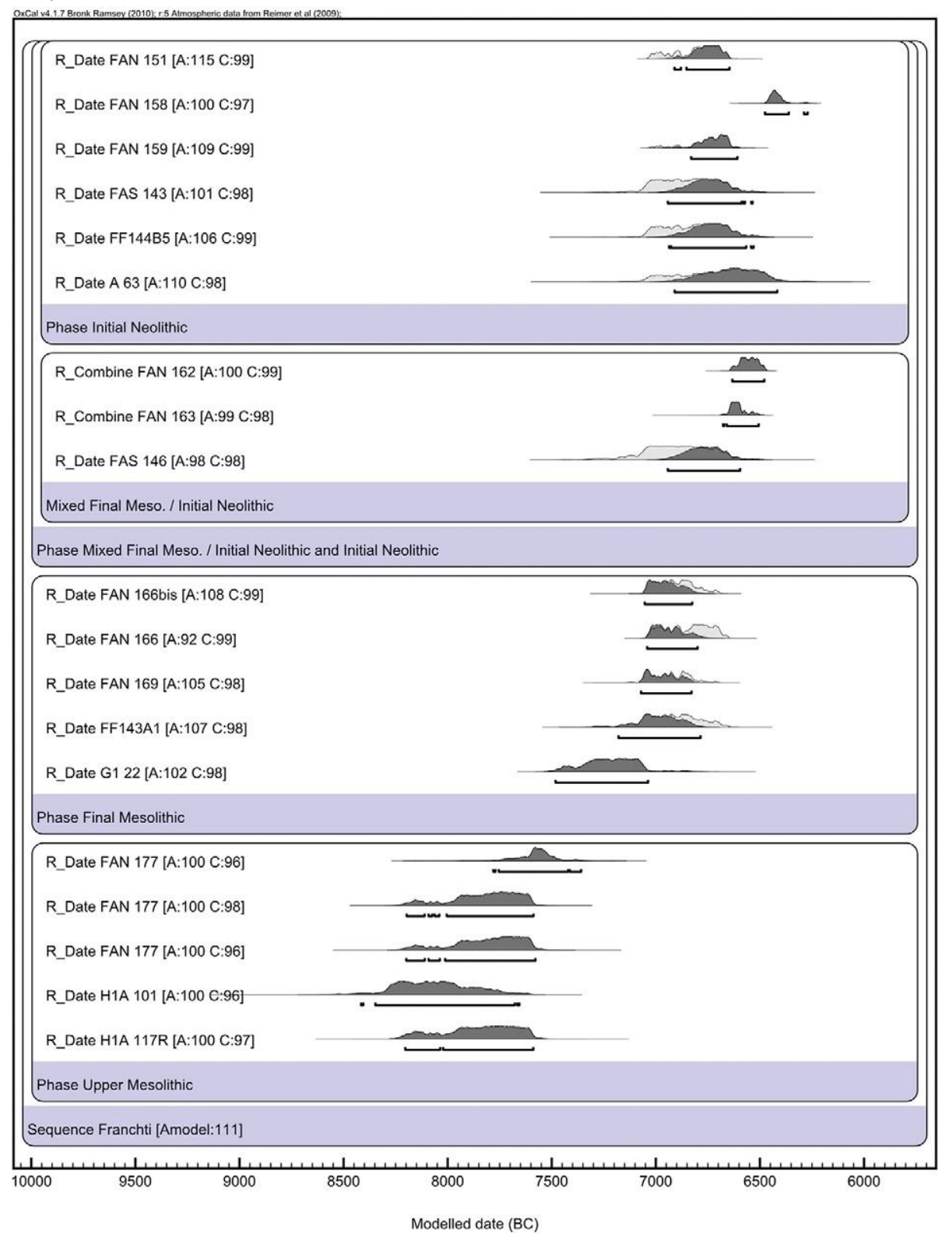



and Initial Neolithic.

indeed possible for FAS 146 which is included in the rocky layer X1. The other charcoal dates suggest a time gap of around 100 years between the Final Mesolithic and the Initial Neolithic, whereas the dates on seeds suggest an interval of c. 200 years. This short interval is probably compatible with both Farrand's observation of some weathering of the Final Mesolithic rocky layer X1 (Farrand 2000: 51) and the strong continuity in the chipped stone tool assemblages, marine molluscs and ornaments between the Final Mesolithic and Initial Neolithic (Shackleton 1988: figs. 3 and 4; Perles 1990:116, 2013). It reinforces the suggestion that the Initial Neolithic reflects a phenomenon of acculturation by local (ex-)hunter-gatherers (Perles 1990). On the other hand, our new dates obviously do not' solve the problem of the status, 'aceramic' or 'ceramic', of the Initial Neolithic. The few sherds found in some units of the 'grey clay' stratum in FAN and FAS all belong to dominant Early Neolithic wares. They can be alternatively considered as intrusive, or as evidence for very scarce use of pots (Vitelli 1993: 39). No new data can be added to this ongoing discussion.

The demonstrated presence of Neolithic farmers at or around Franchthi during the first half of the seventh millennium leaves open the possibility of a brief episode of strictly local significance, as suggested early on by Thissen (2000: 191-92). Whether or not the Early Neolithic follows more or less directly at Franchthi cannot be confirmed from the few and unsatisfactory Early Neolithic dates available. The answer to this question requires another dating programme, focusing on the thick Early Neolithic deposits from Paralia and not the shallow and largely disturbed Early Neolithic deposits within the cave (Vitelli 1993: 44).

\section{Conclusion}

Our results demonstrate that Franchthi was occupied by farmers before 6500 BC, not much later than the earliest occupation of Knossos in Crete, where an oak acorn was recently AMS-dated to 7040-6770 (OxA-9215) (Efstratiou et al. 2004). These results suggest that Crete and southern Greece may have been occupied earlier than Thessaly, where the few dates earlier than $6500 \mathrm{cal} \mathrm{BC}$ come from charcoals, not seeds. No Early Neolithic site has recently been excavated or dated in Thessaly, however, and earlier settlements may well await discovery. Greece can still produce unexpected results concerning the Early Neolithic, as shown by the recent series of dates from Dikili Tash and Mavropigi which demonstrate that Macedonia may have been settled as early as 6500 cal BC (Karamitrou-Mentessidi et al. 2013; Lespez et al. 2013).

All these new dates confirm the antiquity of the Neolithic in Greece, which, on presently available evidence, precedes the earliest Neolithic occupations in Bulgaria by three to five centuries (Higham et al. 2011), in Italy by five to seven centuries (Binder in 
press), and in Spain by at least one millennium (Zilhao 2011). This shows clear phenomena of arrhythmia $\sim$ in the spread of the Neolithic in Europe.

Except for an early seventh millennium date at Ulucak (Derin pers. comm. June 2013), the earliest dates from Franchthi are also slightly older than the currently available dates from sites such as Yes silova, Ege Gubre and Araplı in western Anatolia, Hoca Cesme in . Turkish Thrace or Ugurlu on the Aegean island of Gokc eada, which do not go back beyond c. 6500 BC (Reingruber \& Thissen 2005; C ilingiroglu \& C $C_{s}$ ilingiro` glu 2007; Sa glamtimur 2007; Derin et al. 2009; Erdogu 2011). Radiocarbon dates, therefore, cannot be taken ${ }^{\longleftarrow}$ to demonstrate the chronological anteriority of the western Anatolian Neolithic over the Greek one. There is no doubt, on the other hand, that the Early Neolithic in Macedonia and Bulgaria shows strong links with western Anatolia and compatible radiocarbon dates.

The radiocarbon chronology, as available today, thus concurs with archaeological data and supports a model of multiple origins for the introduction of the Neolithic in Europe.

\section{Acknowledgements}

We gratefully acknowledge a grant from INSTAP for renewed work on Franchthi Cave, and a grant from the Agence Nationale de la Recherche (ANR-06-Blan-0273). We should like to thank Mrs Evelyne Kaltnecker and all the members of the LMC14 laboratory for skilful processing of the samples dated at Artemis. We also express our thanks to the CNRS and the CEA for their support, and to two anonymous reviewers, who greatly helped to improve this paper.

\section{References}

ALLEY, R.B., P.A. MAYEWSKI, T. SOWERS, M. STUIVER, K.C. TAYLOR \& P.U. CLARK. 1997. Holocene climate instability: a prominent, widespread event 8200 yr ago. Geology 25: 483-86.

AMMERMAN, A.J. \& L.L. CAVALLI-SFORZA. 1971. Measuring the rate of spread of early farming in Europe. Man NS 6: 674-88.

- 1984. The Neolithic transition and the genetics of populations in Europe. Princeton (NJ): Princeton University Press.

ARNOLD, M., E. BARD, P. MAURICE \& J.C. DUPLESSY. 1987. ${ }^{14} \mathrm{C}$ dating with the Gif-surYvette Tandetron accelerator: status report. Nuclear Instruments and Methods in Physics Research B29: 120-23.

BINDER, D. In press. Mesolithique et Neolithique' ancien en Italie et dans le sud-est de la France entre 7000 et $5500 \mathrm{BCE}$ cal: questions ouvertes sur les dynamiques culturelles et les proces d'interaction,' in J. Jaubert, N. Fourment \& P. Depaepe (ed.) Transitions, ruptures et continuit'e durant la Pre'ehistoire, Actes du XXVlle Congr'es pr'ehistorique de France (Bordeaux - Les Eyzies, 2010). Paris: Societ' e' prehistorique franc aise. $^{\prime}$

BOCQUET-APPEL, J.-P., S. NAJI, M. VANDER LINDEN \& J. KOZLOWSKI. 2009. Detection of diffusion and contact zones of early farming in Europe from the time-space distribution of ${ }^{14} \mathrm{C}$ dates. Journal of Archaeological Science 36: 807-20. 
Early seventh-millennium AMS dates from domestic seeds in the Initial Neolithic

BRONK RAMSEY, C. 2001. Development of the radiocarbon calibration program. Radiocarbon 43(2A): 355-63.

- 2009. Bayesian analysis of radiocarbon dates. Radiocarbon 51: 337-60.

$\mathrm{C}_{s}$ ILINGIROGLU, A. \& C. C ILINGIROGLU. 2007. Ulucak, in M. Ozdögan \& N. Bas sgelen (ed.) 'Turkiye'de“" Neolitik Donem, Yeni Kazılar, Yeni Bulgular" : 361-72. Istanbul: Arkeoloji ve Sanat Tayinlari.

CLARK, J. 1965. Radiocarbon dating and the spread of farming economy. Antiquity 39: 45-48.

DAVISON, K., P.M. DOLUKHANOV, G.R. SARSON \& A. SHUKUROV. 2006. The role of waterways in the spread of the Neolithic. Journal of Archaeological Science 33: 641-52.

DERIN, Z., A. FILIZ \& C. TAYFUN. 2009. Izmir'in prehistorik Yerles simi-Yes ilova Hoy" u“g g u 2005-2006“ yılı $C_{s}$ alı smaları. Arkeoloji Dergisi 13: $1-58$.

DIAMANT, S. 1979. A short history of archaeological sieving at Franchthi Cave, Greece. Journal of Field Archaeology 6: 203-17.

EFSTRATIOU, N., A. KARETSOU, E. BANOU \& D. MARGOMENOU. 2004. The Neolithic settlement of Knossos: new light on an old picture, in G. Cadogan, E. Hatzaki \& E. Vasilakis (ed.) Knossos: palace, city, state (British School at Athens Studies 12): 43-49. London: British School at Athens.

ERDOGU ${ }^{\sim}$, B. 2011. A preliminary report from the 2009 and 2010 field seasons at Ugurlu on the island of " Gokc, eada." Anatolica 37: 45-65.

FARRAND, W.R. 2000. Depositional history of Franchthi Cave, sediments, stratigraphy and chronology. With a report on the background of the Franchthi Project by T.W. Jacobsen (Excavations at Franchthi Cave, Greece, fasc. 12). Bloomington: Indiana University Press.

GKIASTA, M., T. RUSSELL, S. SHENNAN \& J. STEELE. 2003. Neolithic transition in Europe: the radiocarbon record revisited. Antiquity 77: 45-60.

HANSEN, J.M. 1991. The palaeoethnobotany of Franchthi Cave (Excavations at Franchthi Cave, Greece, fasc. 7). Bloomington: Indiana University Press.

HIGHAM, T., C. BRONK RAMSEY, F. BROCK, D. BAKER \& P. DITCHFIELD. 2011. Radiocarbon dates from the Oxford AMS system: archaeometry datelist 34. Archaeometry 53: 1067-84.

JACOBSEN, T.W. 1969. Excavations at Porto Cheli and vicinity, preliminary report, II: the Franchthi Cave, 1967-1968. Hesperia: 343-81.

JACOBSEN, T.W. \& W.R. FARRAND. 1987. Franchthi Cave and Paralia. Maps, plans and sections (Excavations at Franchthi Cave, fasc. 1). Bloomington: Indiana University Press.

KARAMITROU-MENTESSIDI, G., N. EFSTRATIOU, J.K.

KOZLOWSKI, M. KACZANOWSKA, Y. MANIATIS, A.

CURCI, S. MICHALOPOULOU, A. PAPATHANASIOU \& S.M. VALAMOTI. 2013. New evidence on the beginning of farming in Greece: the Early Neolithic settlement of Mavropigi in western Macedonia (Greece). Antiquity 87(336). Available at: http://antiquity.ac.uk/projgall/mentessidi336/ (accessed 17 June 2013).

KOTSAKIS, K. 2001. Mesolithic to Neolithic in Greece.

Continuity, discontinuity or change of course? Documenta Praehistorica 28: 63-73. 


\section{Catherine Perlès, Anita Quiles \& Hélène Valladas}

KYPARISSI-APOSTOLIKA, N. 2006. The beginning of the Neolithic in Thessaly, in I. Gatsov \& H. Schwarzberg (ed.) Aegean - Marmara - Black Sea: the present state of research on the Early Neolithic: 59-67. Langenweissbach: Beier \& Beran.

LESPEZ, L., Z. TSIRTSONI, P. DARCQUE, H. KOUKOULI-CHRYSSANTHAKI, D.

MALAMIDOU, R. TREUIL, R. DAVIDSON, G. KOURTESSI-PHILIPPAKIS \& C. OBERLIN. 2013. The lowest levels at Dikili Tash, northern Greece: a missing link in the Early Neolithic of Europe. Antiquity 87: 30-45.

MUNRO, N. \& M. STINER. 2012. Franchthi Cave annual report. Zooarchaeological studies. Paper presented at the ASCSA open meeting, Athens, March 9, 2012.

PAYNE, S. 1975. Faunal change at the Franchthi Cave from 20000 BC to 3000 BC, in A.T. Clason (ed.) Archaeozoological studies: 120-31. The Hague: Elsevier.

PERLES, C. 1990. Les industries lithiques taill'ees de Franchthi (Argolide, Gr`ece). Tome II: les industries du M’esolithique et du N'eolithique initial (Excavations at Franchthi Cave, fasc. 5). Bloomington: Indiana University Press.

- 2001. The Early Neolithic in Greece. The first farming communities in Europe. Cambridge: Cambridge University Press.

-2004. Les industries lithiques taill'ees de Franchthi

(Argolide, Gr'ece). Tome III: du N’eolithique ancien au N'eolithique final (Excavations at Franchthi Cave, fasc. 13). Bloomington: Indiana University Press.

-2005. From the Near East to Greece: let's reverse thefocus. Cultural elements that didn't transfer, in C. Lichter (ed.) How did farming reach Europe? Anatolian-European relations from the second half of the $7^{\text {th }}$ through the first half of the $6^{\text {th }}$ millennium cal BC (Byzas 2): 275-90. Istanbul: Deutsches archaologisches Institut Abteilung Istanbul."

-2010. Grece et Balkans: deux voies de p' en' etration' distinctes du Neolithique en Europe? in J.-P.' Demoule (ed.) La r'evolution N'eolithique dans le monde: 263-81. Paris: CNRS.

- 2013. Tempi of change: when soloists don't playtogether. Arrhythmia in 'continuous' change. Journal of Archaeological Method and Theory 20: 281-99. http://dx.doi.org/10.1007/ s10816012-9164-1

PINHASI, R., J. FORT \& A.J. AMMERMAN. 2005. Tracing the origin and spread of agriculture in Europe.

PLoS Biology 3: 2220-28. http://dx.doi.org/

10.1371/journal.pbio.0030410

RASSE, M. 2008. La diffusion du Neolithique en’ Europe (7000-5000 av. J.-C. et sa representation' cartographique. M@ppemonde 90(2). Available at: http:/ / mappemonde.mgm.fr/num18/articles/ art08205.html (accessed 5 June 2013).

REIMER P.J., M.G.L. BAILLIE, E. BARD, A. BAYLISS, J.W. BECK, P.G. BLACKWELL, C. BRONK RAMSEY, C.E. BUCK, G.S. BURR, R.L. EDWARDS, M. FRIEDRICH, P.M. GROOTES, T.P. GUILDERSON, I. HAJDAS, T.J. HEATON, A.G. HOGG, K.A. HUGHEN, K.F. KAISER, B. KROMER, F.G. MCCORMAC, S.W. MANNING, R.W. REIMER, D.A. RICHARDS, J.R. SOUTHON, S. TALAMO, C.S.M. TURNEY, J. VAN DER PLICHT \& C.E. WEYHENMEYER. 2009. IntCal09 and Marine09 radiocarbon age calibration curves, $0-$ 50,000 years cal BP. Radiocarbon 51: 1111-50. 
Early seventh-millennium AMS dates from domestic seeds in the Initial Neolithic

REINGRUBER, A. \& L. THISSEN. 2005. ${ }^{14} \mathrm{C}$ database for the Aegean catchment (eastern Greece, southern Balkans and western Turkey), in C. Lichter (ed.) How did farming reach Europe? Anatolian-European relations from the second half of the $7^{\text {th }}$ through the first half of the $6^{\text {th }}$ millennium cal BC (Byzas 2): 295-327. Istanbul: Deutsches archaologisches“" Institut Abteilung Istanbul.

- 2009. Depending on ${ }^{14} \mathrm{C}$ data: chronological frameworks in the Neolithic and Chalcolithic of southeastern Europe. Radiocarbon 51: 751-70.

RENFREW, C. 1973. Before civilization: the radiocarbon revolution and prehistoric Europe. New York: Knopf.

ROSE, M. 1995. Fishing at Franchthi Cave, Greece: changing environments and patterns of exploitation. Old World Archaeology Newsletter 18(3): 21-26.

RUNNELS, C.N. 2003. The origins of the Greek Neolithic: a personal view, in A.J. Ammerman \& P. Biagi (ed.) The widening harvest: looking back, looking forward: 121-32. Boston (MA): Archaeological Institute of America.

SA $_{\text {Glamtimur }}$, H. 2007. Ege Gubre Neolitik Yerle simi,“” in M. Ozdo“ $\quad$ gan \& N. Ba sgelen (ed.) Turkiye'de Neolitik Donem. Yeni Kazılar, Yeni Bulgular" : 373-84. Istanbul: Arkeoloji ve Sanat Yayınları.

SAMPSON, A. 2005. New evidence from the early productive stages in the Aegean Basin from the $9^{\text {th }}$ to the $7^{\text {th }}$ millennium cal BC, in C. Lichter (ed.) How did farming reach Europe? AnatolianEuropean relations from the second half of the $7^{\text {th }}$ through the first half of the $6^{\text {th }}$ millennium cal BC (Byzas 2): 131-41. Istanbul: Deutsches archaologisches“. Institut Abteilung Istanbul.

SEF' ERIAD' ES`, M. 2007. Complexity of the processes of Neolithization: tradition and modernity of the Aegean world at the dawn of the Holocene period (11-9 kyr). Quaternary International 167-168: 177-85.

SHACKLETON, J.C. 1988. Marine molluscan remains from Franchthi Cave (Excavations at Franchthi Cave, fasc. 4). Bloomington: Indiana University Press.

THEOCHARIS, D.R. 1973. Neolithic Greece. Athens: National Bank of Greece.

THISSEN, L. 2000. Early village communities in Anatolia and the Balkans, 6500-5500 cal BC. Studies in chronology and culture contact. Unpublished $\mathrm{PhD}$ dissertation, Leiden University.

- 2005. Coming to grips with the Aegean in prehistory: an outline of the temporal framework, in C. Lichter (ed.) How did farming reach Europe? Anatolian-European relations from the second half of the $7^{\text {th }}$ through the first half of the $6^{\text {th }}$ millennium cal BC (Byzas 2): 29-40. Istanbul: Deutsches archaologisches Institut Abteilung Istanbul."

VANDEN LINDEN, M. 2011. In constant motion? Recent advances in mathematical modelling and radiocarbon chronology of the Neolithisation of Europe, in A. Hadjikoumis, E. Robinson $\& \mathrm{~S}$.

Viner (ed.) The dynamics of Neolithisation in Europe. Studies in honour of Andrew Sherratt: 26-45. Oxford \& Oakville (CT): Oxbow.

VITELLI, K.D. 1993. Franchthi Neolithic pottery. Vol. 1: classification and ceramic phases 1 and 2 (Excavations at Franchthi Cave, fasc. 8). Bloomington: Indiana University Press.

WEINBERG, S.S. 1970. The Stone Age in the Aegean, in The Cambridge ancient history I, part 1: 557-672. Cambridge: Cambridge University Press.

WENINGER, B., E. ALRAM-STERN, E. BAUER, L. CLARE, U. DANZEGLOCKE, O. JORIS, C. KUBATSKI, G. ROLLEFSON, H. TODOROVA \& T. VAN ANDEL. 2006. 


\section{Catherine Perlès, Anita Quiles \& Hélène Valladas}

Climate forcing due to the $8200 \mathrm{cal} \mathrm{yr} \mathrm{BP} \mathrm{event} \mathrm{observed} \mathrm{at} \mathrm{Early} \mathrm{Neolithic} \mathrm{sites} \mathrm{in} \mathrm{the} \mathrm{eastern}$ Mediterranean. Quaternary Research 66: 401-20.

ZILHAO , J. 2011. Time is on my side..., in A. Hadjikoumis, E. Robinson \& S. Viner (ed.) The dynamics of neolithisation in Europe. Studies in honour of Andrew Sherratt: 46-65. Oxford \& Oakville (CT): Oxbow. 